\title{
SMART SYSTEM FOR AUTOMATIC CROP AND RECOGNITION PLAT NUMBER
}

\author{
Desti Fitriati' ${ }^{1}$, Nira Ravika Pasha ${ }^{2}$, Bambang Hariyanto ${ }^{3}$, Amir Murtako ${ }^{4}$, \\ Sri Rezeki Candra Nursari ${ }^{5}$, \\ Informatics Engineering, Faculty of Engineering 1,23,4,5 \\ Universitas Pancasila ${ }^{1,2,3,4,5}$ \\ desti.fitriati@univpancasila.ac.id¹, niraravika96@gmail.com², bbghariyanto@yahoo.com³, \\ amir.murtako@univpancasila.ac.id ${ }^{4}$, sri.rezeki.candra.n@univpancasila.ac.id ${ }^{5}$
}

\begin{abstract}
Abstrak
Berdasarkan data dari Badan Pusat Statistik tahun 2018 dituliskan bahwa jumlah sepeda motor untuk wilayah Indonesia yaitu sebanyak 120,10 Juta atau 82\% dan untuk mobil sebanyak 26,75 juta atau sekitar 18\% dari populasi keseluruhan. Dengan meningkatnya populasi pengguna kendaraan bermotor, maka akan mengakibatkan meningkatnya masalah yang terjadi pada pelanggaran lalu lintas dan juga sistem keamanan teknologi pada sistem parkir. Sistem parkir yang ada saat ini sebagian besar masih membutuhkan tenaga petugas parkir. Selain itu, sistem yang sudah ada juga hanya membahas tentang buka-tutup palang, dan pemberian informasi lahan parkir. Meskipun sistem yang ada sudah ada yang menggunakan kecerdasaan buatan untuk pembacaan nomor plat, namun pencocokan masih dilakukan oleh petugas. Tentu hal ini menjadi tidak efektif dan efisien karena penggunaan kecerdasan buatan tidak murni dilakukan oleh sistem. Untuk mengatasi hal ini, maka solusi yang diberikan pada penelitian ini adalah membuat sistem parkir yang dapat melakukan pembacaan nomor plat secara otomatis dan menyimpan data masuk kendaraan secara langsung ke database. Sistem yang dibuat pula dapat membuka-tutup palang pintu secara otomatis. Teknik pengolahan citra template matching dipilih untuk menyelesaikan permasalahan ini. Berdasarkan hasil percobaan, system dapat mengenali nomor plat dengan akurasi sebesar 83\%. Untuk penelitian lanjutan, maka diperlukan pengenalan kepemilikan kendaraan dan pemberian informasi lahan parkir agar sistem parkir menjadi lebih sempurna.
\end{abstract}

Kata kunci: Pengolahan Citra, Template Matching, Sistem Parkir Otomatis, Pelat Nomor Kendaraan

\begin{abstract}
Based on data from the Central Statistics Agency in 2018, it was written that the number of motorbikes for the Indonesian region was 120.10 million or $82 \%$ and for cars 26.75 million or around $18 \%$ of the total population. With the increasing population of motorized vehicle users, it will result in an increase in problems that occur in traffic violations and also the technology security system in the parking system. Most of the existing parking systems still require parking attendants. In addition, the existing system only discusses the opening and closing of bars and providing information on parking lots. Although the existing system already uses artificial intelligence to read plate numbers, the officers are still matching it. Of course this is not effective and efficient because the use of artificial intelligence is not purely done by the system. To overcome this, the solution given in this study is to create a parking system that can read plate numbers automatically and store vehicle entry data directly into the database. The system created can also open and close the door latch automatically. The template matching image processing technique was chosen to solve this problem. Based on the experimental results, the system can recognize plate numbers with an accuracy of $83 \%$. For further research, it is necessary to introduce vehicle ownership and provide parking information so that the parking system becomes more perfect.
\end{abstract}

Keywords: Image Processing, Templates Matching, Automatic Parking Systems, Vehicle Number Plates

\section{INTRODUCTION}

Currently, the means of transportation that have a very big role for human needs are vehicles, both motorbikes and cars. This has led to increased use of vehicles. Data from the Central Bureau of
Statistics in 2018 (BPS Indonesia, 2018) which came from the Indonesian Police Office stated that the number of motorbikes for the Indonesian territory was 120.10 million or $82 \%$ of the total number of vehicles in Indonesia. As for cars 26.75 million or approximately $18 \%$ of the total. The 
increasing population of motorized vehicle users will result in an increase in problems that occur in traffic violations and also the technology security system in the parking system (Putra \& Santosa, 2017).

The parking system that is widely researched and developed is the parking information system. However, research and development on automation processes that ensure the safety of parking lots is still rare. The current parking system for security purposes still requires officers. Officers in parking lots have a duty to compare the license plate number on the vehicle with the license plate number on the ticket and the time of entry (Sarief, Biu, \& Chandra, 2019)

Vehicle number plates are unique and are only owned by one vehicle per vehicle plate series because the number plate system in Indonesia is a legacy from the Dutch East Indies colonial division based on residency areas (Budianto, Adji, \& Hartanto, 2015). After running for a long time, the reference is still used until now which consists of two lines, namely the first line consisting of the residency area code followed by the police number of the type of motorized vehicle and the last is the area code of the residency, the second line is the validity period of the number plate which consists of month and year (Saputra, Winardi, Mudjanarko, \& Inayati, 2017). The designation varies according to the basic color of the number plates, the colors on the number plates are black, red, yellow, and white. As well as the police logo as copyright and number plate brand holders in Indonesia (Masdiyasa, Bhirawa, \& Winardi, 2019). This makes it easier for parking attendants to recognize and secure the vehicle.

Currently, the detection of vehicle plates in the Pancasila University campus parking lot can be done manually by parking officers by matching existing vehicle plates with conventional data stored in records. However, conventional methods are quite time consuming and unsafe (Michael, Tanoto, Wibowo, Lutan, \& Dharma, 2019). Some people who enter campus often claim to be students or lecturers so that parking fees are free. To apply the automation process to parking lots, a modeling system is needed as a reference in replacing some of the officers' functions. One of the most guaranteed system modeling methods that can be applied is image processing technology (Sarief et al., 2019)

Based on data from the South Sulawesi Regional Police Public Relations on November 30, 2016, it was recorded that during 2 weeks of zebra operations in a location, 504 traffic violations were found, namely 430 motorcyclists and the remaining 74 car drivers. The police number listed on the license plate of the vehicle can be used by the authorities as evidence of a motorist committing a traffic violation. The large number of vehicles makes it difficult for police officers to recognize vehicle number plates manually, so a system that can recognize vehicle license plates automatically and quickly is needed Detection of Motor Vehicle Police Numbers Based on Digital Images Using Binaryization and Tempale Matching Methods

In this study, researchers used image processing to detect vehicle plate numbers in Indonesian format using template matching method. Template matching will compare input data with previously recognized data used for training. This method makes use of the similarity template to check the similarities between one image and another (Wibawa, 2020) . The closer the pixel values are between the images, the closer they will be to the input image. The use of this method can be used in applications that use a template matching algorithm to recognize letters in documents in the form of digital (Hafidz, Ananda, \& Akbar, 2019). Template matching is an example of an application that can recognize characters in digital images (Rohpandi, Sugiharto, \& Aji Winara, 2015). This application modeling can be used as a reference in implementing the vehicle parking system on the Pancasila University campus where vehicle plate number detection is carried out automatically (Sarief et al., 2019).

With this application modeling, it is hoped that the detection process on vehicle number plates on the Pancasila University campus will take place faster because it is carried out automatically using a template matching algorithm so as to prevent the passing of parking fees for people claiming to be lecturers or students and also expected to prevent vehicle theft at In addition, the existence of this application can be important in the development of the Intelligent Transportation System (ITS) technology and security systems in Indonesia.

\section{RESEARCH METHODS}

\section{Types of research}

This research is an experimental research where trials are carried out to get the best accuracy from the knowledge gained in the training process

\section{Time and Place of Research}

Data obtained from vehicle plates were collected from live photoshoots on the Pancasila University campus during March to June 2020.

\section{Research Target / Subject}

The subject of this study is the image of the vehicle plate both motorbikes and cars, where the 
scope of the image taken is the front view image. While the target of this study is cutting the characters printed on the vehicle plates, then continued with character recognition and storing vehicle plate information into the database.

\section{Procedure}

The stages carried out in this study generally consist of 3 processes, namely the preprocess stage, the template matching stage, the results evaluation stage. The proposed research design can be seen in Figure 1 below.

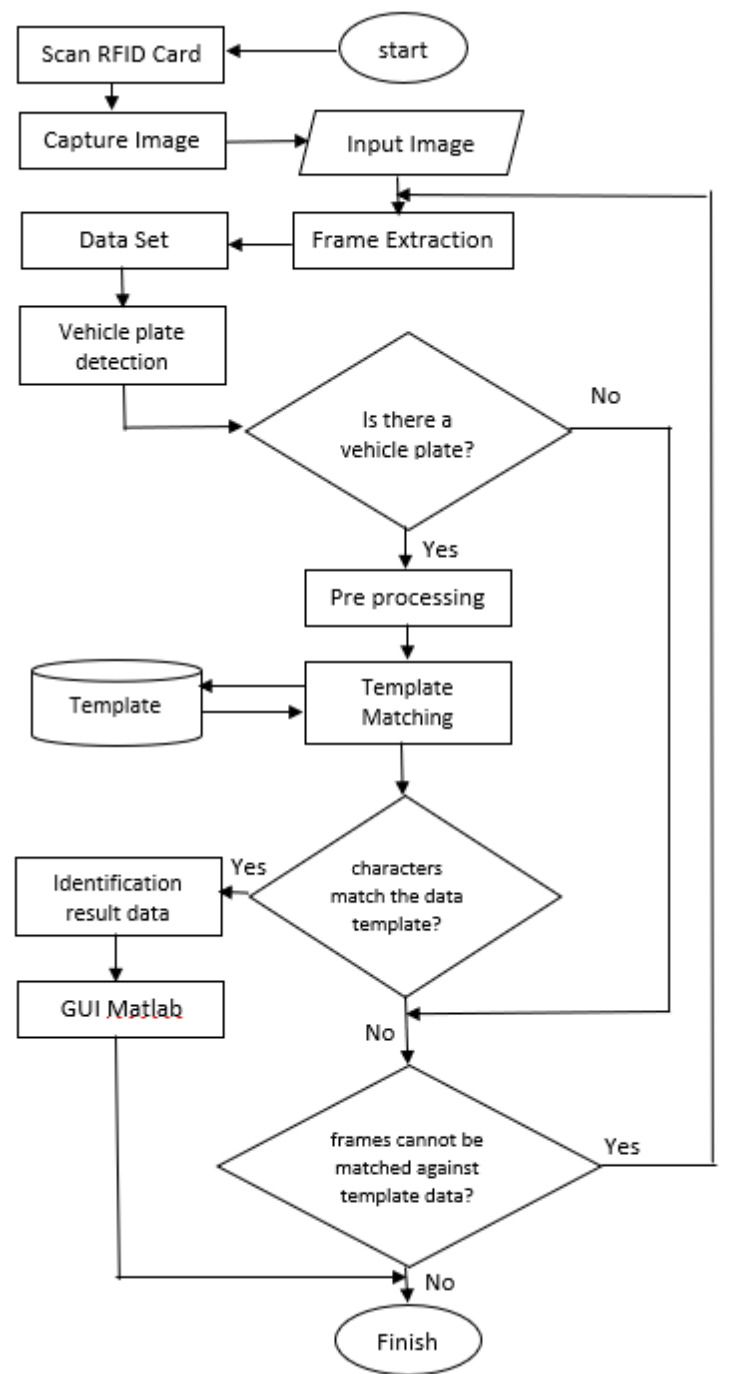

Figure 1. Proposed Method Design

At the data processing stage, this study uses a template matching algorithm to recognize patterns in images. The first stage of the process, namely the digital image preprocessing stage occurs after the system takes pictures at the beginning using a camera.

The next stage is segmentation which is done to separate one character from another character. The results of this segmentation stage are several images that have been taken from the entire image of the vehicle number plate. The images that are the result of the segmentation process will be normalized or resized before being processed with a template matching algorithm.

The image size from the normalization process is adjusted to the size of the template image in the database so that the pixel values in the two images can be compared. After being normalized, the next step is feature extraction, which is taking the characteristics of the detected and normalized image, such as checking the shape and size of the characters to be compared in the final process.

The final process of detecting a number on a vehicle plate is a character recognition process using a template matching algorithm. Template matching is an algorithm that is widely used to recognize patterns, this algorithm has been chosen because of its very simple and easy implementation. The input image will be compared with the image contained in the database. The input image is used as the center of the part of the digital image to be compared and how many points are calculated according to the template. This step is repeated until the entire image has been compared with the input image. After the closest point suitability value or the smallest minimum error between the input image and the image contained in the database, it indicates that the image is the most suitable image with the input image. Finally, to calculate the testing accuracy of this system using confusion matrix evaluation technique which will be calculated by comparing the number of detected letters with the total number of letters. In general, the process flow can be seen in Fig. 2, at each stage there are methods used to complete the research.

At the processing stages, this research using Template matching algorithm which is the process of finding an object (template) for all objects in an image. The template is compared with the whole object and if the template matches (close enough) to an unknown object in the image then that object is marked as a template (Wijayanti, 2018). The level of conformity between the input image and the template image can be determined by calculating the smallest error value. The template with the smallest error value is the template that best matches the input image to be compared. The level of suitability (Ibnutama, Panjaitan, \& Ginting, 2019) between the input images from the template image can be calculated based on the smallest error value using equation (1) $\min =\sum(,) \in W(I,-T)$,2 .

Information:

I = is the input image pixel pattern to be compared. 
$\mathrm{T}=$ is the pixel pattern of the template image.

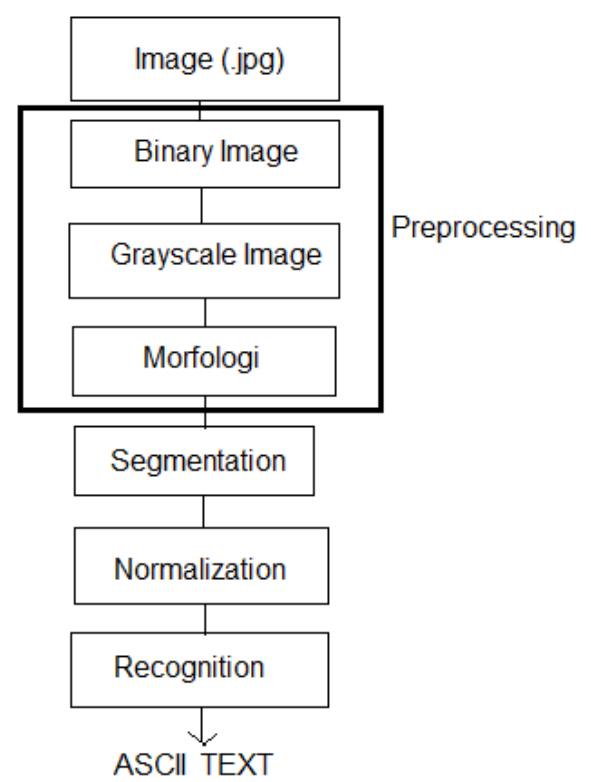

Figure 2. Pre processing Stage

Template Matching is executed, when the input process matches the memory template. The storage template for the image data is alphanumeric taken from the numbers 0-9 and the letters A-Z with a total of 36 types recognition(Gumelar, Fibriani, Setiabudi, \& Supeno, 2016). The letters and numbers for each picture are taken from the license plate of the vehicle whose writing follows the predetermined standard. All image save templates are increased in size to $24 \times 42$ pixels in bmp format and saved in file folder. The function of the memory template is the same as the database (Irawati, 2011), so that when the number plate detection system processes the recognition by matching the input character with the memory template it gives good results at the time of. The following is an overview of a memory template for image recognition of vehicle license plates (Figure 3).

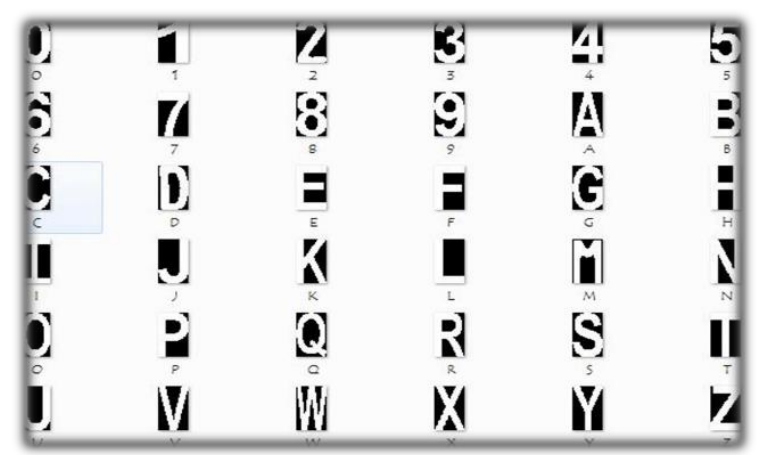

Figure 3. Internal Template Storage

\section{Data, Instruments, and Data Collection Techniques}

The data used in this study are primary data, where the data in the form of an image of the vehicle plate is taken directly at the research location. image retrieval of vehicle plates that will enter from the campus entrance area. Image is taken using a camera that is positioned in the campus entrance area. The cameras are positioned in such a way that the captured image contains all parts of the vehicle's license plate.

The camera used is high resolution so that the image captured is also high resolution so that the digital image information is more accurate. After the image from the vehicle containing the number plate is taken and put in a certain folder which will be processed using matlab software, the next process is preprocessing which consists of three stages, namely binary image (thresholding), grayscalling, and morphology (dilation, erosion and morphology of binary images).

\section{Data analysis technique}

From the results of calculations using the template matching method, evaluation is carried out by making the average accuracy of all data using equation (2) :

Accuracy $=($ correct data $/ \mathrm{N}$ data $) * 100 \% \ldots \ldots \ldots . .$.

\section{RESULTS AND DISCUSSION}

The initial step of image processing at the pre-processing stage aims to improve the original image so that it produces a better image for processing at the processing stage. The preprocessing stage to improve the image of motor vehicle license plates consisting of image input, grayscale, dilation and erosion, abstracts. The following is the process of the pre-processing stages:

1. Input Image

The data set retrieval process used as input to the system to be designed is a vehicle number plate image in .jpg format. The following is an overview of the image input process, this stage describes how the input image can appear on the layout axes GUIDE Matlab.

2. Grayscalling

In this grayscaling process, a colored input image can be converted into a grayscale image consisting of white and black using RGB color representation. Fig. 4 are the results of the process of changing the input image into a grayscale image. 
JURNAL RISET INFORMATIKA

Vol. 3, No. 2 March 2021
P-ISSN: 2656-1743 |E-ISSN: 2656-1735

DOI: https://doi.org/10.34288/jri.v3i2.183

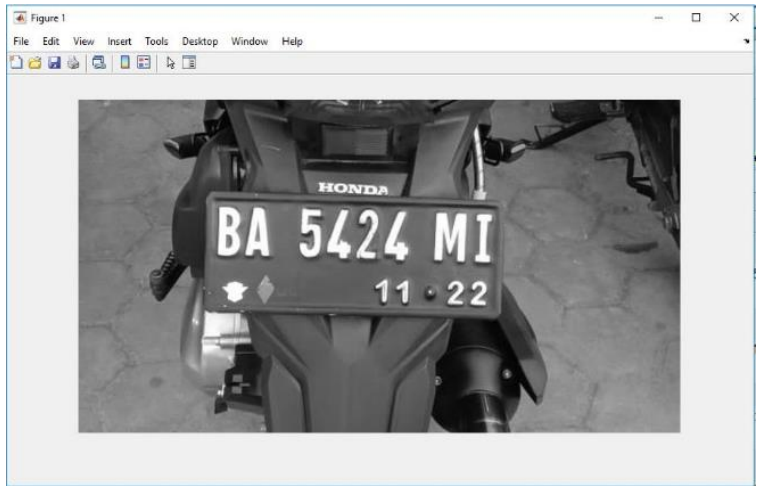

Figure 4. Grayscale Image

In this median filtering process, the input image that has become a grayscale image will be removed salt-and-pepper noise, by replacing the image pixel value with the median or the middle value of the neighboring pixels. Figure 5 below are the results of the grayscale image change process by removing noise.

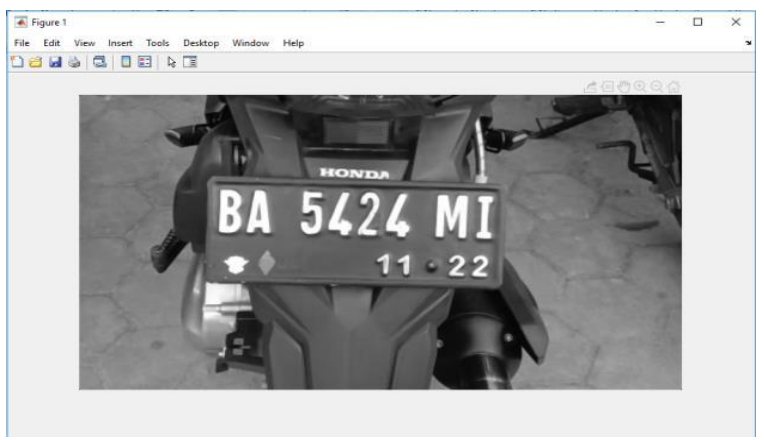

Figure 5. Media Tapis Image Filter

\section{Dilation and Erosion}

Dilation and erosion operations are a process of thickening and thinning an image. Dilation will add pixels to the boundaries between objects in a digital image, while erosion will make the image size smaller. These two operations will set and select the size of the kernel matrix (structuring element). Figure 6 below is the process of dilation and erosion.

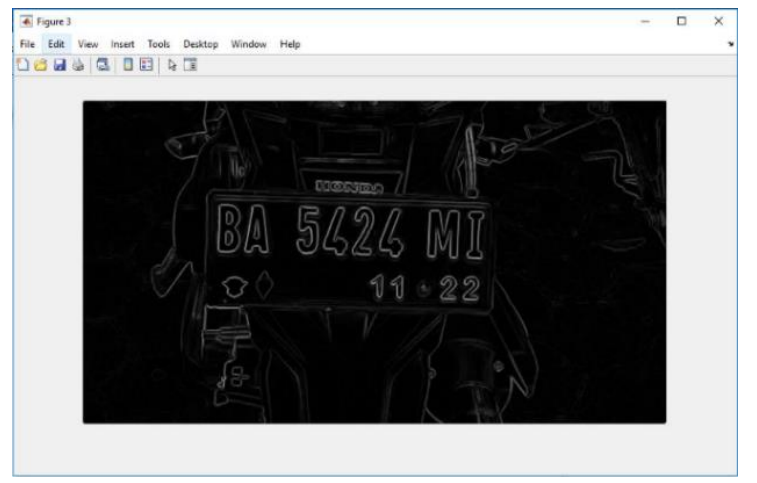

Figure 6. Dilation and Erosion Result

\section{Imsubstract}

Imsubstract operation is the process of adding light or reducing light to the image. Imsubstract operation will add light to the dilation and erosion process, to clarify the results of dilation and erosion. Figure 7 below are the imsubstract process applied after the dilation and erosion process.

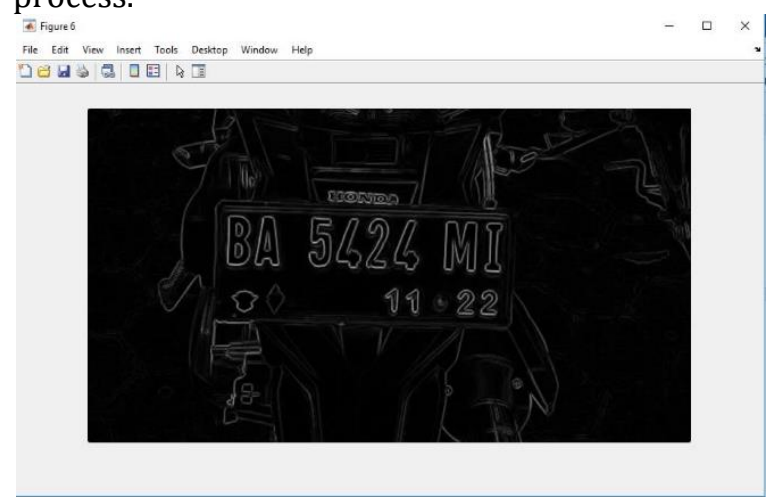

Figure 7. Imsubstract Result

\section{Convolution}

Convolution is a process where an image is manipulated using an external mask to produce a new image. The following is the convolution process (Figure 8):

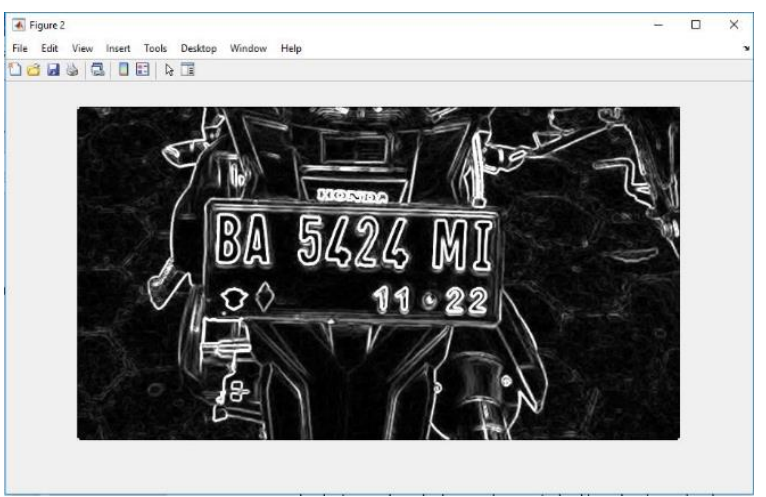

Figure 8. Convolution Result

6. Imadjust

Imadjust is a process in which the convoluted image is adjusted to the image intensity value. Imadjust will map image intensity values to new values. Fig. 9 below imadjust processes are carried out.

\section{Thresholding}

At the threshold process, the intensity value of an image that is more than or equal to the threshold value will be changed to white (0), while the image intensity value that is less than the threshold value will be changed to black (1). If the pixel value is above an intensity value it will be changed to 0 (white), which means that the pixel is 
the background, while the intensity value is below the specified value limit, the pixel will be changed to black (1) which is considered a character. The image resulting from the process will be subjected to a thresholding process then converted into a matrix that is sized according to the predetermined pixel size. Furthermore, it will be converted into a binary matrix vector form which only values 0 and 1 for each pixel. Figure 10 below are the results of the thresholding process.

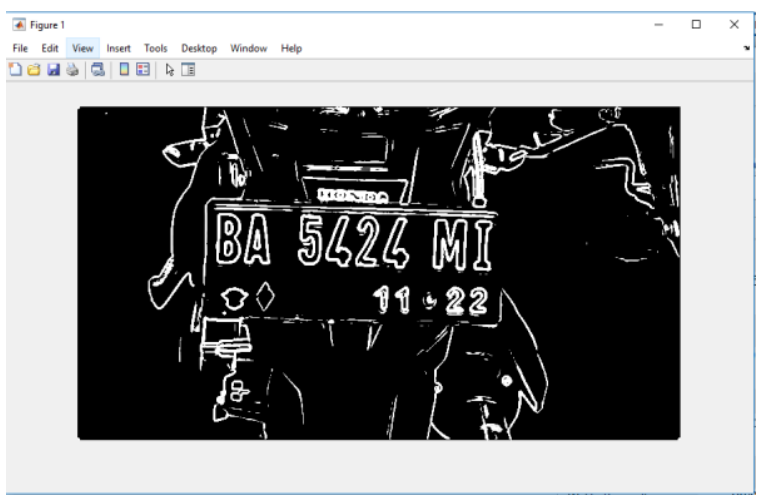

Figure 9. Imadjust Result

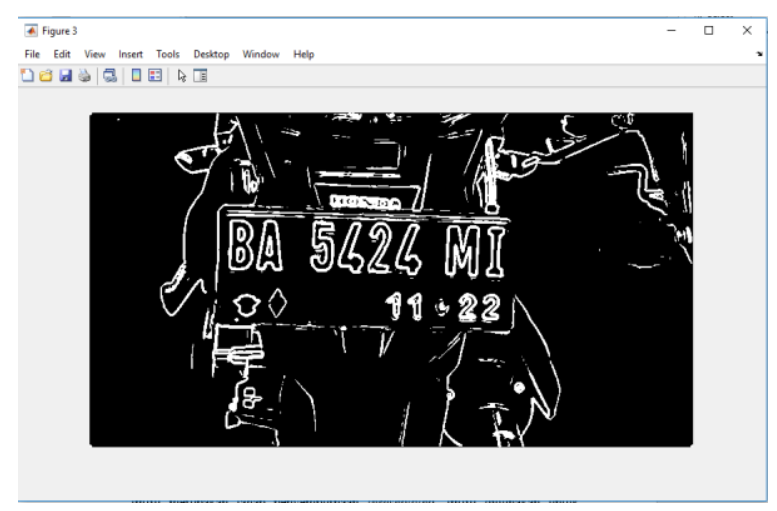

Figure 10. Image Thresholding Result

8. Imfill

Imfill is a thresholding refinement stage. Imfill is used to fill in empty image areas such as holes. Figure 11 below are the imfill process:

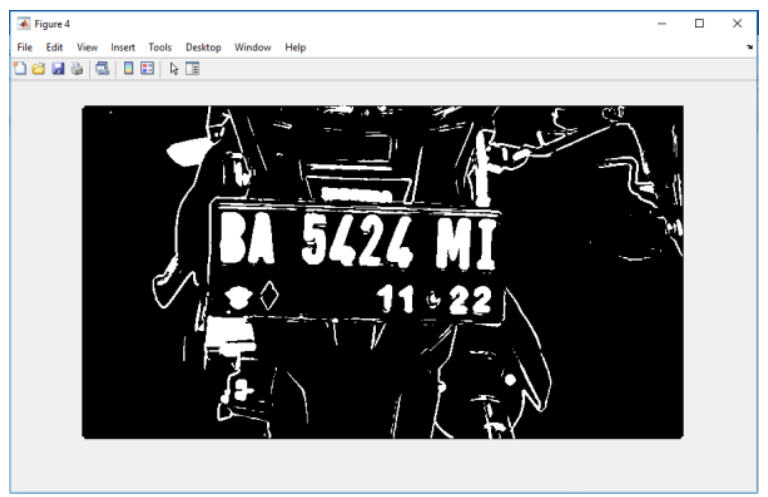

Figure 11. Imfill Result
9. Imrode

Imerode is an image abrasive process. Imerode is used to scrape the gray scale binary image from the infill result. Figure 12 below are the imerode process.

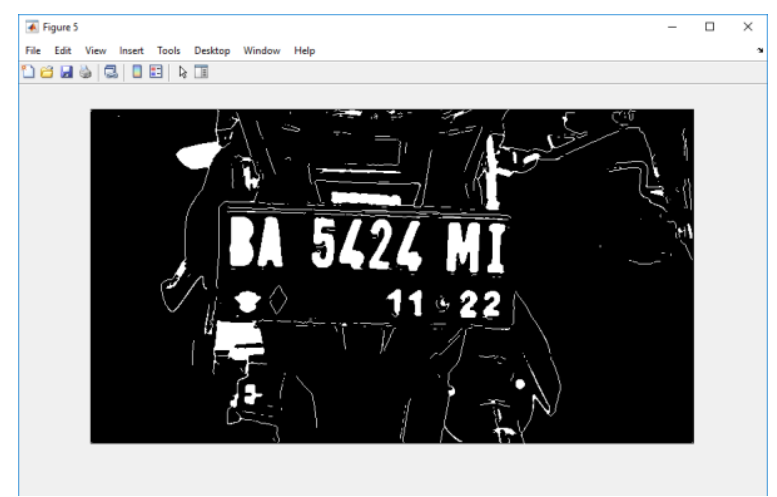

Figure 12. Imrode Result

10. Bwmorph

Bwmorph is a morphological operation process on binary images. Bwmorph is used for the process of removing interior pixels by leaving the outline of the image. Figure 13 below are bwmorph processes are carried out.

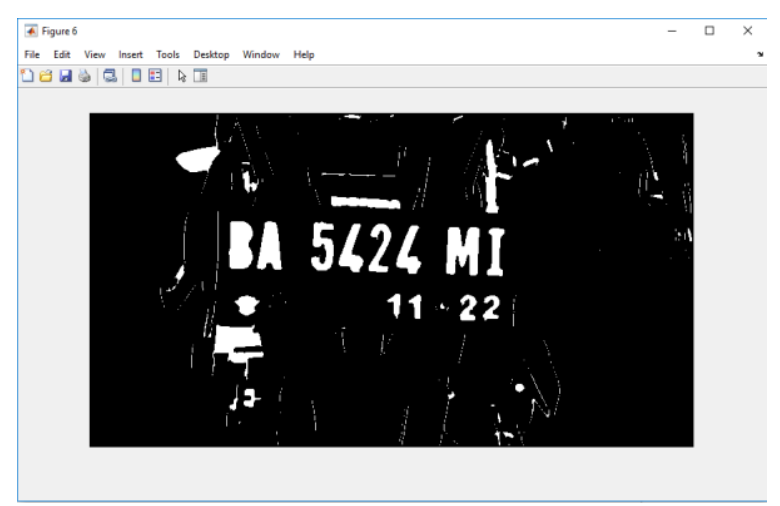

Figure 13. Bwmorph Result

\section{Segmentation}

The segmentation process is an important initial step in the process of recognizing character patterns on vehicle number plates. The method used in the segmentation process is letter segmentation. To get the distance between letters, generally the output of image segmentation is in the form of binary coding where the desired object is black (1), while the background that is removed is white (0). In the segmentation process, it is done by mapping the number of black dots for each line in the image to the $y$-axis and each line of characters from the mapping results is mapped again to the $\mathrm{x}$ axis. Fig. 14 below is the segmentation process. 


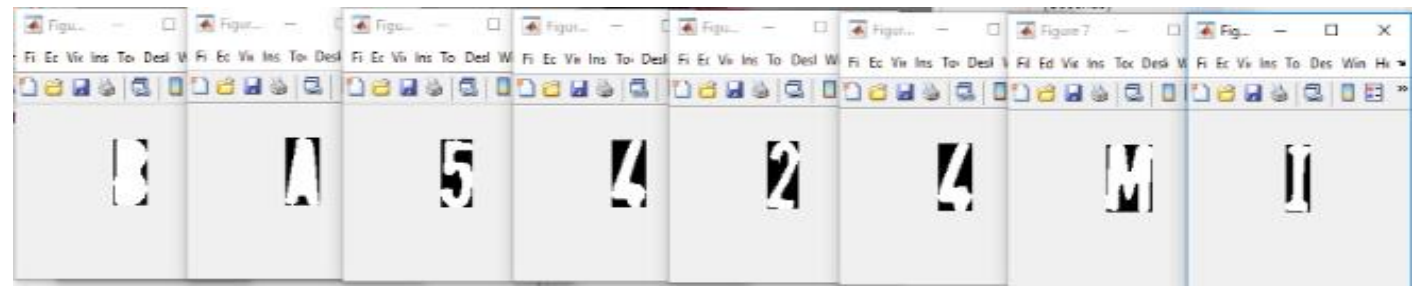

Figure 14. Segmentation Result

Figure 15 below is a display of applications that have been made in this study.

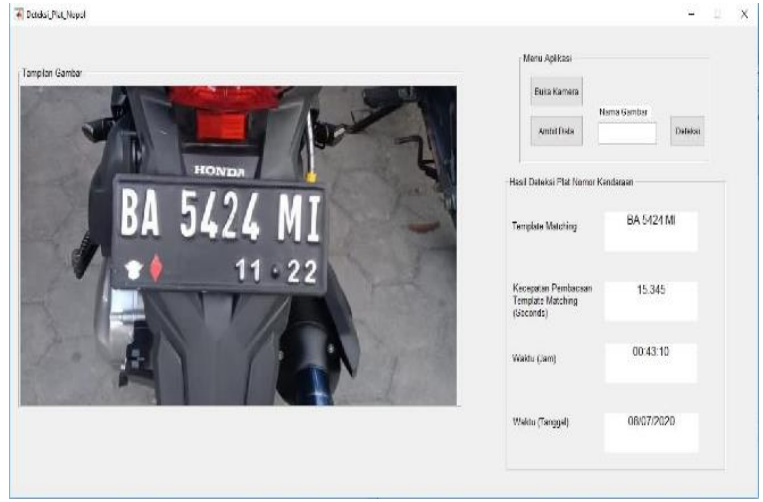

Figure 15. Interface from this Application Research

The results of system testing are the results of comparison testing between the results of calculations carried out by the system and manual calculations. The results of this test are conducted to determine the accuracy results obtained from the confusion matrix which provides more detailed information about the performance of the model.

The data is grouped based on detection accuracy. Each group is added and implemented into a formula to find the average accuracy. Figure 16 below is the result of testing the matching template.

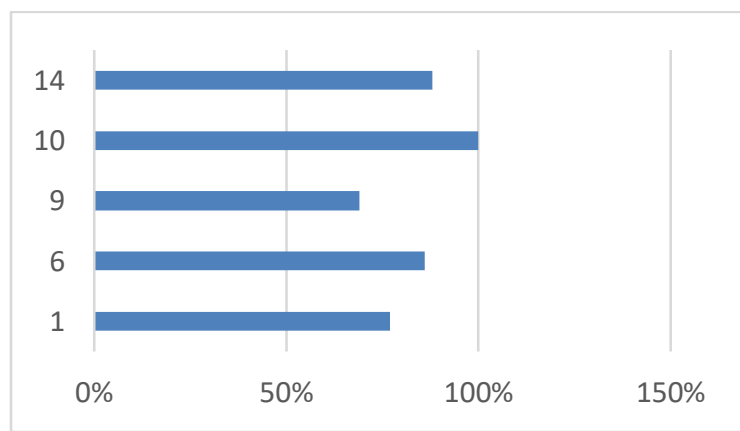

Figure 16. Testing of Template Matching

Figure 16 shows the results of the tests that have been carried out, the total number of data tested is 50 image data, with the Template Matching method test data with $100 \%$ accuracy of 10 image data, $88 \%$ accuracy of 14 image data, 86\% accuracy of 6 image data, 83 accuracy $\%$ of 1 image data, $75 \%$ accuracy of 9 image data, 71\% accuracy of 1 image data, $63 \%$ accuracy of 9 image data. If calculated using the average formula, the resulting average accuracy is $83 \%$. Table 1 below shows the testing methods of this study.

Table 1. Example of Template Matching Test

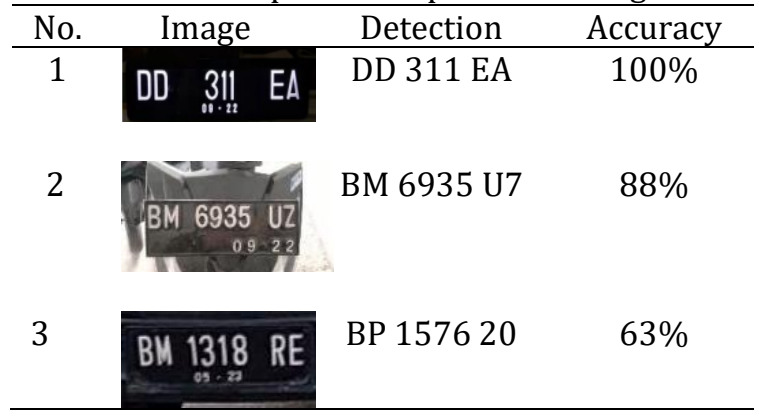

\section{CONCLUSIONS AND SUGGESTIONS}

\section{Conclusion}

Based on the results of the study, that the Template Matching method for data with a total of 50 test data and 66 training databases. Then the results from Template Matching produce an average accuracy of $83 \%$. It can be concluded that this method is able to detect vehicle number plates quite well

\section{Suggestion}

based on the trials conducted there are limitations given and make the results not flexible and do not meet real world conditions. Therefore, further research is required to readjust the captured image, so that the image taken can be from various positions.

\section{REFERENCES}

BPS Indonesia. (2018). Statistik Transportasi Darat 2018. Jakarta: Land Transportation Statistics 2018. Retrieved from https://www.bps.go.id/publication/2019/11 /27/7fdd3379108b4a60e046f4c8/statistik- 
transportasi-darat-2018.html

Budianto, A., Adji, T. B., \& Hartanto, R. (2015). Deteksi Nomor Kendaraan Dengan Metode Connected Component dan SVM. Jurnal Teknologi Informasi Magister, 1(1), 106-117. Retrieved from https://jurnal.darmajaya.ac.id/index.php/jti $\mathrm{m} /$ article/view/489

Gumelar, M. G., Fibriani, I., Setiabudi, D., \& Supeno, B. (2016). Analisis Sistem Pengenalan dan Keamanan Kriptografi Hill Cipher pada Plat Nomor Kendaraan Menggunakan Metode Template Matching. Prosiding Seminar Nasional ReTII Ke-11 2016, 13-28. Yogyakarta: ITNY. Retrieved from https://journal.itny.ac.id/index.php/ReTII/a rticle/view/427

Hafidz, H., Ananda, A., \& Akbar, M. (2019). Perbaikan Citra RGB dengan Metode Homomorphic Filtering Menggunakan Butterworth Filter | Jurnal Komputer Terapan. Jurnal Komputer Terapan, 1-1. Retrieved from https://jurnal.pcr.ac.id/index.php/jkt/article /view/6

Ibnutama, K., Panjaitan, Z., \& Ginting, E. F. (2019). Modifikasi Metode Template Matching pada OCR Untuk Meningkatkan Akurasi Deteksi Plat Nomor Kendaraan. Jurnal Teknologi Sistem Informasi Dan Sistem Komputer TGD (JSISKO TECH), 2(2), 21-29. Retrieved from https://ojs.trigunadharma.ac.id/index.php/js $\mathrm{k} /$ article/view/121

Irawati, D. A. (2011). Pengembangan Aplikasi Pengenalan Plat Nomor Kendaraan Roda Dua Pada Area Parkir. Seminar Nasional Sains Dan Teknologi 2015, 1-11. Jakarta: Universitas Muhammadiyah Jakarta. Retrieved from https://jurnal.umj.ac.id/index.php/semnaste $\mathrm{k} /$ article/view/523

Masdiyasa, I. G. S., Bhirawa, S., \& Winardi, S. (2019). Identifikasi Plat Nomor Kendaraan Bermotor Menggunakan Metode Multi-Step Image Processing Berbasis Android. E-NARODROID, 5(1), 17-25. Retrieved from https://jurnal.narotama.ac.id/index.php/nar odroid/article/view/862/

Michael, M., Tanoto, F., Wibowo, E., Lutan, F., \& Dharma, A. (2019). Pengenalan Plat Kendaraan Bermotor dengan Menggunakan Metode Template Matching dan Deep Belief Network. MATRIK : Jurnal Manajemen, Teknik Informatika Dan Rekayasa Komputer, 19(1), 27-36.

https://doi.org/10.30812/matrik.v19i1.475

Putra, E. D., \& Santosa, S. (2017). Optimasi Kemampuan Segmentasi Otsu pada
Identifikasi Plat Nomor Kendaraan Indonesia Menggunakan Metode Gaussian. Pseudocode, 4(1), 47-60. https://doi.org/10.33369/pseudocode.4.1.4 7-60

Rohpandi, D., Sugiharto, A., \& Aji Winara, G. (2015). Aplikasi Pengolahan Citra Dalam Pengenalan Pola Huruf Ngalagena Menggunakan MATLAB. Proceedings Konferensi Nasional Sistem Dan Informatika (KNS\&I), 9(0), 772777. BALI: STMIK STIKOM. Retrieved from http://www.ejournal.stikom-

bali.ac.id/index.php/knsi/article/view/465

Saputra, B., Winardi, S., Mudjanarko, S. W., \& Inayati, I. (2017). IDENTITAS DIGITAL KENDARAAN BERMOTOR DENGAN CHIP WEMOS UNTUK SOLUSI PROGRAM PLAT NOMOR GENAP GANJIL. Seminar Nasional Ilmu Terapan (SNITER), B03-1-B03-8. Surabaya: Universitas Widya Kartika. Retrieved from https://ojs.widyakartika.ac.id/index.php/sni ter/article/view/35

Sarief, I., Biu, H. Y., \& Chandra, S. I. (2019). Automatic Number Plate Recognition Using Template Matching Method. TELEKONTRAN, 7(1), 14-24. Retrieved from https://ojs.unikom.ac.id/index.php/telekont ran/article/view/1634

Wibawa, G. A. (2020). Analisa Kesamaan Aksara Bali Menggunakan Template Matching | JELIKU (Jurnal Elektronik Ilmu Komputer Udayana). Jurnal Elektronik Ilmu Komputer Udayana, 8(4), 507-513. Retrieved from https://ojs.unud.ac.id/index.php/JLK/article /view/59344

Wijayanti, M. (2018). Implementasi Template Matching Correlation Dan K-Nearest Neighbor Untuk Mendeteksi Hukum Bacaan Tajwid Pada Citra Tulisan Al-Qur'an. SimkiTechsain, 2(9), 1-9. Retrieved from http://simki.unpkediri.ac.id/detail/14.1.03.0 2.0304 